
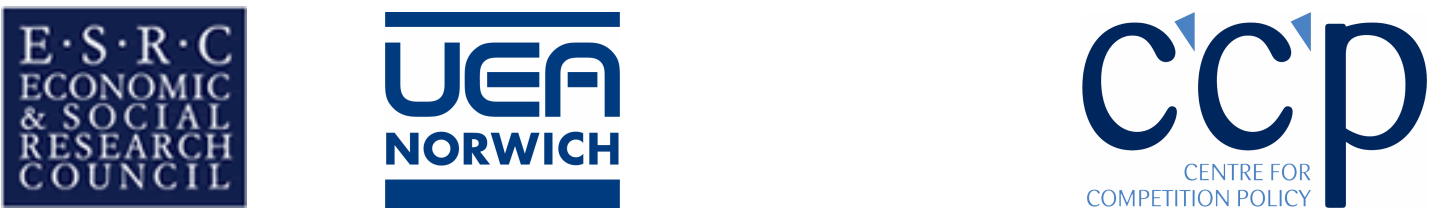

\title{
UK Merger Remedies under Scrutiny
}

\author{
by \\ Michael Harker \\ ESRC Centre for Competition Policy and Norwich Law School, \\ University of East Anglia
}

\section{CCP Working Paper 06-16}

\begin{abstract}
This paper focuses on the Somerfield decision of the Competition Appeal Tribunal (CAT). In that decision, the CAT demonstrated a high degree of deference to the Competition Commission where the latter was scoping divestiture remedies in a merger case. This approach is consistent with the case law of the US and EC and, it is argued, is appropriate given the need for procedural expediency. The decision is placed in the wider context of the debates over the efficacy of merger remedies and the appropriate limits of judicial supervision of agency discretion in this area.
\end{abstract}

\section{October 2006}

JEL Classification Codes: K21

Keywords: Merger Remedies; Divestiture; Merger Appraisal

Acknowledgements:

Thanks to Morten Hviid, Peter Ormosi, Steve Davies, Bruce Lyons, Andrei Medvedev and Andrew Scott for commenting on an earlier draft of this paper. All errors and omissions remain the responsibility of the author. The support of the Economic and Social Research Council is also gratefully acknowledged.

Contact details:

Michael Harker, ESRC Centre for Competition Policy, University of East Anglia, Norwich, NR4 7TJ, UK; t: +44 (0) 1603 593715, f: +44 (0) 1603 591622; m.harker@uea.ac.uk 


\section{Introduction}

This paper discusses the principles underlying the judicial supervision of merger remedies in the UK. Focussing on a recent case of the Competition Appeal Tribunal, Somerfield $v$ Commission, ${ }^{1}$ the problems faced by

competition agencies in scoping divestiture remedies are explored. ${ }^{2}$ The paper concludes that the CAT's approach to the question of agency autonomy in this area is to be applauded.

The Somerfield decision is placed in the wider context of the debate over the procedures and efficacy of merger remedies. Section 1 explains the differing views concerning agency discretion in this area. Given that much of the decisional learning and research exists in the EC and US, section 2 places the UK merger regime in a comparative context while section 3 compares the agency guidelines concerning divestiture in these three jurisdictions. Section 4 then explores the empirical evidence which has emerged in the US and EC, over the potential pitfalls in the scoping of divestiture packages in merger cases. Section 5 discusses the approach of the UK Competition Commission and the CAT to the question of the divestiture remedies in the Somerfield case. Section 6 concludes.

\section{Perspectives on the use and efficacy of merger remedies}

In recent times, there has emerged a consensus among commentators that insufficient attention has been paid to the role of remedies in merger cases. In the US, much criticism has been levelled against the Federal antitrust agencies - the Federal Trade Commission (FTC) and the Antitrust Division of the Department of Justice (DoJ) - that there is a lack of consistency and transparency in this area. Following on from such criticisms, the DoJ issued

\footnotetext{
${ }^{1}$ [2006] CAT 4 (herafter 'the CAT judgment').

2 Behavioural remedies, which are the exception rather than the norm in merger cases, are not discussed here.
} 
new merger remedies guidelines in 2004 together with a commitment that the DoJ and the FTC will work together more closely in future in order to achieve greater consistency across cases. Europe's merger control regime has just undergone significant reform - both in procedural and substantive terms and the question of the efficacy of merger remedies has not escaped attention. The EC Commission's guidelines on merger remedies have been in place since 2000. Both the FTC and, more recently, the EC Commission's Directorate General for Competition (DG Comp) have conducted in-house studies analysing the efficacy of the merger remedies they have imposed in the past, and the results of these studies, which are considered below, have cast further light on some of the potential problems associated with the implementation of divestment packages.

Of the central concerns that have emerged over the use of merger remedies, there are two strands which in many respects are counterposed. On the one hand, allegations have been made that competition agencies have often acted strategically, imposing remedies which go beyond that which is necessary to correct the anti-competitive effects of the mergers in question. ${ }^{3}$ The ability so to do turns on the relative strength of bargaining power of the agencies as compared with the merging parties, which is said to be the product of the merger appraisal process, in particular the dynamics of time and, in the US in particular, the risks of litigation should the agency and the parties be unable to reach agreement. On the other hand, concerns have been expressed over the efficacy of merger remedies imposed. At root the problem is characterised as one of information asymmetry as between the agency and the merging parties, in favour of the latter. Due to this problem, the issue of institutional design should be informed heavily by the need to ensure that merging parties have the appropriate incentives to both reveal the necessary private information to

\footnotetext{
${ }^{3}$ For the US, see for example: Baer and Redcay "Solving Competition Problems in Merger Control: The Requirement of an Effective Divestiture Remedy" (2001) 69 George Washington Law Review 915; Boast "FTC Merger Remedies: Shattering the Myths" (2001) 69 George Washington Law Review 996 (for the agency perspective). For the EC, see for example: Winkler "Some Comments on Procedure and Remedies under EC merger Control Rules: Something Rotten in the Kingdom of EC Merger Control" and Monti "The Commission's Notice on Merger Remedies" (for the agency perspective) both in Shelanski and Lévêque (eds.), Merger Remedies in American and European Union Competition Law (Cheltenham, UK and Northampton, MA, US: Edward Elgar, 2003).
} 
the agencies and act in a way which does not frustrate or subvert the desired remedial outcome. The problems of informational asymmetry and misalignment of incentives have been given credence by both economic models and empirical studies which tend to suggest that firms have both the motives and the means to frustrate merger remedies. These latter concerns are explored in this article.

\section{The mechanics of merger control in comparative context ${ }^{4}$}

Given that much of the literature on merger remedies - both legal and economic - has perforce centred on US and EC case law and practice, it is necessary to place the key characteristics of the UK merger regime in comparative context with these jurisdictions.

In both the US and the EC, mergers which meet certain jurisdictional thresholds must be notified to and scrutinised by the relevant competition authority. The UK merger regime, on the other hand, does not provide for the compulsory notification of mergers, although transactions meeting the relevant jurisdictional thresholds may, subject to a limitation period, be subject to an ex post investigation. ${ }^{5}$ This is, as we shall see, a difference of some significance.

Broadly speaking, all three regimes follow a two-stage investigatory model. The EC merger regime is organised around two investigatory phases: phase I, under which the EC Commission will decide whether or not the merger gives rise to competitive concerns; and, if it does, phase II, where the EC

\footnotetext{
${ }^{4}$ This section represents the briefest of sketches. For a full description of the decision-making procedures in the EC, UK and US see respectively: Navarro, Font, Folguera \& Briones, Merger Control in the EU, (2nd edn, Oxford University Press, 2005) ch. 13; Scott, Hviid \& Lyons, Merger Control in the UK (Oxford University Press, 2006), chs. 13 to 16; Schlossberg (ed), Mergers and Acquisitions: Understanding the Antitrust Issues (2nd edn, American Bar Association, 2004), ch. 2. For a full discussion of the procedures of US and EC law in comparative perspective see Scott "Tweedledum and Tweedledee?: Regime Dynamics in US and EC Merger Control" in Marsden (ed), Handbook on Transatlantic Antitrust (Cheltenham, UK and Northampton, MA, US: Edward Elgar, forthcoming).

${ }^{5}$ With the risk to the parties that the transaction may be unwound or, more probably, a remedies package be imposed subsequently as occurred in the Somerfield case (infra).
} 
Commission will enter into an in-depth investigation of the effects of the merger. ${ }^{6}$ At the end of phases I or II, the EC Commission may either clear the transaction or accept "commitments" from the parties which it is satisfied will remedy the anti-competitive effects of the merger; a prohibition, however, can only be imposed at the end of a phase II investigation. ${ }^{7}$ The relevant agencies in the US, the FTC and the DoJ, have concurrent jurisdiction to scrutinise merger transactions. ${ }^{8}$ Upon notification, the parties must observe an initial waiting period before the merger can be consummated, although this period can be extended by the relevant agency upon the issuance of a request for further information (a "second request"). The second request is equivalent functionally to a phase II investigation by the EC Commission.

Merger appraisal in the UK follows the two-stage model and remedies can be accepted at the end of either phase. However, unlike the EC and US, two agencies are involved sequentially: the first stage is dealt with by the Office of Fair Trading (OFT) whose options are either to clear the merger; to refer the merger to the Competition Commission (hereafter "the Commission"); or to accept undertakings in lieu of such a reference. ${ }^{9}$ Upon a reference to it, the Comission may clear or prohibit the merger, or accept undertakings from the parties. $^{10}$

\footnotetext{
${ }_{7}^{6}$ Respectively, Articles 6 and 8 [ECMR].

${ }^{7}$ The investigatory function is undertaken by DG Comp, the latter charged also with submitting a decision in draft. The formal decision is, however, taken by the College of Commissioners (in respect of phase II decisions) or the Commissioner for Competition acting on their behalf (in respect of phase I decisions).

${ }^{8}$ The requirement to notify was introduced under the Hart-Scott-Rodino Antitrust Improvement Act of 1976 (HSR). Jurisdiction to challenge mergers stems from section 7 of the Clayton Act (15 U.S.C. § 18). Normally the agencies agree between themselves which agency should deal with a merger according to which agency has the greater expertise in respect of a particular sector. In addition, State Attorneys General are also entitled to challenge mergers before the Federal courts in their parens patriae capacity.

${ }^{9}$ Enterprise Act 2002, ss.22 and 33 (in respect of completed and anticipated mergers respectively) and s.73 (undertakings in lieu). There are two key exceptions to the duty to refer or accept undertakings in lieu, namely where the markets are not of sufficient importance to justify a reference to the Commission or where the consumer benefits outweigh the anticompetitive effects of the merger (ss.22(2) and 33(2)).

${ }^{10}$ Enterprise Act 2002, ss.35 and 36 (in respect of completed and anticipated mergers respectively). The Commission is placed under a duty to remedy, mitigate or prevent the anticompetitive effects of the merger in question (ss.41, 82 and 84).
} 
One important difference, however, between the US regime and its EC and UK counterparts is that in the US, the Federal courts, rather than the agencies, are charged with the ultimate decision over whether a merger should be prohibited. In reality, however, very few merger cases are litigated: the vast majority of transactions subject to a second request are either cleared, abandoned or subject to a negotiated settlement. ${ }^{11}$ In respect of the courts' role in the UK merger regime, it follows more closely the EC rather than the US, with the decisions of the OFT and the Commission being the subject of the supervisory jurisdiction of the Competition Appeal Tribunal (CAT). ${ }^{12}$

Some further differences are worthy of explicit mention. In the EC, the onus is on the merging parties to put forward a package of remedies within a tightly prescribed time-frame. The EC Commission then "market tests" these commitments and this assessment forms part of the formal merger decision and the decision in this regard is subject to the supervisory jurisdiction of the Community Courts. The US system is more opaque; generally speaking, merger remedies are negotiated and their terms contained in a consent decree enforceable by the courts. The picture in the UK is dependent upon which of the two competent agencies - the OFT or the Commission - is dealing with the question of remedies. Reflecting the spirit of expediency underpinning a first stage investigation, undertakings will only be accepted by the OFT in lieu of a reference where it is "confident that the competition concerns identified can be resolved without the need for further investigation"; they should accordingly be "clear cut" and "capable of ready implementation". ${ }^{13}$ The EC Commission's guidelines make similar provision in

\footnotetext{
${ }^{11}$ As Blumnethal observes: "the HSR framework shifted the primary locus of merger review activity from the courts to administrative agencies" ("Reconciling the Debate over Merger Remedies: A Discussant's Proposed Decision Rule" (2001) 69 George Washington Law Review 978, 979). For a useful summary and explanation of the enforcement statistics see: The Antitrust Practice Group, "Trends in US government antitrust enforcement", (2004, October) The Antitrust Review of the Americas, p.1.

${ }^{12}$ Enterprise Act 2002, s.120(4) provides that in reviewing a merger decision the CAT "shall apply the same principles as would be applied by a court on an application for judicial review". For an elaboration of the principles underlying this review process see OFT and others $v$ IBA Health [2004] EWCA Civ 142.

${ }^{13}$ OFT, Mergers: Substantive Assessment Guidance (OFT 516, 2003), para. 8.3.
} 
respect of commitments acceptable at the end of the phase I investigation. ${ }^{14}$ The Competition Commission's procedures are more elaborate, involving the publication of an interim remedies report upon which the merging parties and others are consulted. ${ }^{15}$ The following section elaborates upon the substantive content of the agency guidelines on the use of divestiture remedies.

\section{Agency guidelines on merger remedies}

In the Somerfield case, the Commission was applying its recently formulated guidelines on divestiture remedies together with its general merger guidelines. ${ }^{16}$ Given their central importance to the case, it is useful to discuss the former in some detail, comparing them with cognate guidelines in the US and EC. ${ }^{17}$

The Commission's guidelines express a presumption in favour of divestment, principally because such an approach ordinarily involves a "clean break" without the need for continued supervision of the remedy post-transaction. ${ }^{18}$ In the US and EC, this approach has been approved by both the US Supreme Court and the EC Court of First Instance and is given expression in the respective agency guidelines. ${ }^{19}$ In respect of timescale, like the US and EC

\footnotetext{
${ }^{14}$ EC Commission Notice on remedies applicable under Council Regulation (EEC) 4064/89 and Commission Regulation (EC) 447/98, OJ [2001] C68/3 (hereafter "the EC Guidelines") provide: "phase I remedies are designed to provide a straightforward answer to a readily identifiable competition concern" (para. 37).

${ }^{15}$ Application of divestiture remedies in merger inquiries: Competition Commission Guidelines (CC 8, December 2004) (hereafter "the Divestiture Guidelines"), para. 1.9. For a detailed explanation see Scott et al., cited above fn.4, pp.314-27.

${ }^{16}$ The Divestiture Guidelines, ibid.; Merger References: Competition Commission Guidelines (CC 2, June 2003) (hereafter "the Merger Guidelines").

${ }_{17}$ US Department of Justice, Antitrust Division Policy Guide to Merger Remedies, October 2004 (hereafter "the DOJ Guidelines"); the EC Guidelines, cited above fn.14.

${ }^{18}$ Divestiture Guidelines, cited above fn.5, para.1.8.

${ }_{19}$ United States v E.I. Du Pont de Nemours, 366 U.S. 316, 330-31 (1961); California v American Stores Co., 495 U.S. 271, 280-81 (1990); Case T-102/96, Gencor v Commission [1999] ECR II-753, para. 319; DOJ Guidelines, cited above fn.17, pp.7-8; EC Guidelines, cited above fn.14, para.9.
} 
guidelines, the Commission "will tend to favour a remedy that can be expected to show results in a relatively short period". 20

According to its merger guidelines, the Commission, when choosing between two remedies both equally effective, "will choose the remedy that imposes the least cost or that is least restrictive". ${ }^{21}$ Likewise, the US guidelines state that the costs of implementation (including agency, welfare and parties' costs) will be relevant in assessing potential remedies. ${ }^{22}$ While the Commission will generally consider the costs of implementing a remedy, a post-transaction remedy represents an "avoidable cost" and it "will not normally consider the costs of divestment to the parties as it is open to the parties to make merger proposals conditional on competition authorities' approval". ${ }^{23}$ In respect of US and EC, this issue does not arise directly since notification is compulsory for those transactions meeting the respective jurisdictional tests.

In the most straightforward case, where the merging parties are present in the same market (i.e., there is a horizontal overlap), the competition agency will require typically the divestment of assets to achieve the objective of restoring the competitive status quo ante. Divestment can be to a new entrant, thereby creating a new source of competition in the market, or to an existing player, strengthening the competitive constraint facing the merged entity. ${ }^{24}$ All of the guidelines highlight the potential obstacles to achieving this objective. The Commission's guidelines, for example, explain three key risks which might limit the effectiveness of a divestment remedy: composition risks, such that the scope of the divestment package may be too narrow either to attract a suitable purchaser or allow a purchaser to operate effectively in the market; purchaser risks, such that either the merging parties will dispose of the assets

\footnotetext{
${ }^{20}$ Divestiture Guidelines, cited above fn.15, para. 4.16; DOJ Guidelines, cited above fn.17, pp.29-30; EC Guidelines, cited above fn.14, para.10.

${ }_{21}$ Merger Guidelines, cited above fn.16, para. 4.9.

22 DOJ Guidelines, cited above fn.17, pp.7-9.

${ }^{23}$ ibid., para.4.10 (emphasis supplied). The Guidelines continue: "It is for the parties concerned to assess whether there is a risk that a completed merger would be prohibited subsequently and the Commission will normally expect this risk to be reflected already in the acquisition price" (ibid.).

${ }^{24}$ Divestiture Guidelines, cited above fn.15, para. 2.1; DOJ Guidelines, cited above fn.17, p.4; EC Guidelines, cited above fn.14, para.13.
} 
to a weak or otherwise inappropriate purchaser or that a suitable purchaser is not present at all; and asset risks, such that the assets to be divested will deteriorate prior to their disposal. ${ }^{25}$ This useful rubric captures the main concerns highlighted in the US and EC guidelines. ${ }^{26}$ Nevertheless, as is discussed in the following section, persuasive empirical evidence exists to suggest that these risks have been or are given insufficient attention in the US and EC context.

The issue of purchaser risks was central to the Commission's approach in the Somerfield case. Its guidelines place considerable emphasis upon the identification of suitable purchasers for divested assets, of particular relevance here, the "capability" of a purchaser: it "must have the necessary financial resources, incentives, and access to appropriate expertise and assets to enable the divested business to develop as an effective competitor in the market". ${ }^{27}$ For this and other reasons, the Commission makes clear that it will in appropriate circumstances require the identification of an upfront buyer of the divested assets, particularly if there may be "a limited pool of suitable purchasers". ${ }^{28}$ Both the US and EC guidelines make similar provision. ${ }^{29}$ While the Commission did not require an upfront buyer in the Somerfield case, it did seek to limit those who would be eligible to purchase the divested stores, together with prescribing which of Somerfield's assets should be divested. Both of these points proved to be controversial and were addressed by the CAT in detail.

\footnotetext{
${ }^{25}$ Divestiture Guidelines, ibid., para. 2.4.

${ }^{26}$ DOJ Guidelines, cited above fn.17, pp.9-17; EC Guidelines, cited above fn.14, paras.14-21.

${ }_{27}^{27}$ Divestiture Guidelines, cited above fn.15, para. 4.1.

${ }^{28}$ ibid., para. 4.5.

${ }^{29}$ DOJ Guidelines, cited above fn.17, pp.32-33; EC Guidelines, cited above fn.14, paras.1920.
} 


\section{The empirical evidence on the efficacy of merger remedies ${ }^{30}$}

The most well-known and influential study of merger remedies was undertaken by the staff of the FTC and published in $1999 .^{31}$ The study sought to test the success of a sample of divestment packages ordered by the agency between 1990 and $1994 .^{32}$ The benchmark for success was relatively low: whether the purchaser of the divested asset(s) was able to enter the relevant market within a reasonable time and maintain operations in it. According to this standard, around three quarters of the divestments were successful. $^{33}$ In 2005, the DG Comp published the results of an in-house study on the effectiveness of merger remedies. ${ }^{34}$ Broadly speaking, it followed a similar methodology to the FTC's study and drew conclusions which were strikingly similar. ${ }^{35}$ Overall, it concluded that there were "serious design and/or implementation issues affecting the effectiveness of remedies" in 79 per cent of divestiture remedies scrutinised, although 70 per cent of these issues were resolved after three to five years. ${ }^{36}$

The FTC study underlined the importance, in some circumstances, of ensuring that the assets divested represented a viable ongoing business, especially where the purchaser was not already present in the market. ${ }^{37}$ The failure to do so had in some cases resulted in the buyers being forced to

\footnotetext{
${ }^{30}$ No such agency study has been conducted in the UK, although the OFT, DTI and Competition Commission did commission an ex post evaluation of ten mergers which the latter had cleared (OFT, Ex post evaluation of mergers, OFT767 (London: OFT, 2005)).

${ }_{31}$ Baer, A Study of the Commission's Divestiture Process, Prepared by the Staff of the Bureau of Competition of the Federal Trade Commission (Washington DC: FTC, 1999) (hereafter 'the FTC study').

32 Data was collected in respect of 37 divestment orders. The data was mainly in the form of interviews with the buyers of the assets divested. For the purposes of the study, divestment included the licensing of intellectual property.

${ }^{33}$ FTC study, cited above, fn.31, p.10.

${ }^{34}$ DG Comp, Merger Remedies Study (Brussels: European Commission, 2005) (hereafter 'the DG Comp study').

${ }^{35}$ The summary given here draws on chapter 5 of the report. The study comprised ex post analyses of 40 of the EC Commission's merger decisions where commitments were offered and accepted by the EC Commission. This amounted to around 40 per cent of the merger decisions involving commitments during the reference period (1996 to 2000). In total, 96 different remedies were considered, 84 of which involved a divestiture. It employed an interview methodology, although unlike the FTC study, it had a broader pool of interviewees going beyond, in particular, the purchasers of the divested assets. It also was not limited to the consideration of divestment commitments as had been the FTC study.

${ }_{36}^{36}$ DG Comp study, cited above, fn.34, pp.139 to 140.

${ }^{37}$ FTC study, cited above, fn.31, pp.10-11.
} 
maintain post-divestment relationships with the sellers (in the forms, for example, of supply or technical assistance relationships) which exposed the buyer to harmful strategic behaviour by the seller. ${ }^{38}$ Similarly, the EC study found that for those divestment remedies which were ineffective or only partially effective, the main cause was the inadequate scope of the divested business. ${ }^{39}$

Turning to the dynamics of the divestiture process, the FTC admitted candidly that its staff had "assumed a rough balance of information and bargaining power" between sellers and potential buyers. ${ }^{40}$ The results of the study, on the other hand, indicated that buyers were at a potential "substantial disadvantage" in both respects. ${ }^{41}$ Sellers tended to prefer their weakest competitors as buyers in the hope that these buyers would fail to exploit successfully the assets. Likewise, the DG Comp report suggested that there was a systemic bias (on the part of sellers) in favour of divesting to the "weakest purchasers". ${ }^{42}$ While FTC staff had assumed that the buyers had a relatively strong bargaining position, in practice buyers perceived themselves to be in no such advantageous position, appearing to be unwilling to bargain effectively for fear of forfeiting the sale of the assets to a competitor. ${ }^{43}$ In informational terms, even apparently sophisticated multi-national companies were unaware of the major economic characteristics of the markets into which they were entering, with the consequence that they often paid too much and failed to secure the necessary components of a stand-alone business. As a consequence of these results, the FTC concluded that it had been misguided to assume parity of information and bargaining power. Even where buyers appeared satisfied with the terms of divestment, this should not be sufficient:

\footnotetext{
${ }^{38}$ ibid., p.12. There were other cases, however, where a continued relationship between seller and buyer was critical to the success of the buyer (ibid.).

${ }^{39}$ DG Comp study, cited above, fn.34, p.140.

${ }^{40}$ FTC study, cited above, fn.31, p.15.

41 ibid., pp. 15 to 16.

42 DG Comp, cited above, fn.34, p.149.

${ }^{43}$ FTC study, cited above, fn.31, pp.15-16. The assumption that buyers were in a superior bargaining position stemmed from the apparent advantages of bidding on a compulsory divestiture which had to be concluded within a prescribed time period and without a minimum price.
} 
“...staff must attempt to balance the bargaining power between buyers and [sellers] in order to protect the remedies that the [FTC] orders". ${ }^{4}$

The corrective prescriptions to guard against divestment packages which were too narrow in scope were mirrored broadly in both reports. Merging parties tended to urge very narrow packages, and it was necessary to resist this. ${ }^{45}$ Moreover, buyers did not tend to inform the FTC when they were having problems negotiating a satisfactory package. ${ }^{46}$ All of these problems and others suggested that the FTC should play an explicit supervisory role in the divesture process which might consist in: selecting appropriate buyers (even to the extent of scrutinising buyers' business plans); ${ }^{47}$ requiring the divestiture of a 'crown jewel' if the merged entity does not complete a divestiture within a given period; ${ }^{48}$ and, in some instances, requiring the appointment of a divestiture trustee, guarding against the potential runningdown of an asset before its eventual sale. ${ }^{49}$ Similarly, the DG Comp report concluded that there was a need for more systematic supervision ex post, with the report proposing that a monitoring trustee be appointed in all divestment cases. ${ }^{50}$

\footnotetext{
${ }^{44}$ ibid., p.16.

${ }^{45}$ For example, in one case, neither the merged entity nor the FTC appointed trustee was able to divest five of the six grocery stores specified in the remedies order and in consequence the divestment had to be abandoned (Promodes, FTC Docket No. 9228, 113 F.T.C. 372 (1990)). For a fuller discussion of the potential pitfalls of a too-narrow divestment package, see FTC study, cited above, fn.31, pp.28 to 29.

${ }^{46}$ ibid., p.26.

47 ibid., pp.32 to 33 .

${ }^{48}$ ibid., p.30. The crown jewel provision is a term in the divestiture order which requires that the merging parties identify a stand-alone asset which they will divest should they be unable to secure a buyer for the original divestment assets. It seeks to avoid the situation mentioned above where the merging parties propose a divestment package which is not viable. ${ }^{49}$ ibid., pp.29 to 30.

${ }^{50}$ DG Comp study, cited above, fn.34, p. 158. The report suggested that increased emphasis be placed upon the identification of upfront buyers and/or the use of crown jewel provisions in appropriate cases (ibid., pp.144 to 145). It also pointed to the problems of merging parties crippling assets in the period between the decision and implementation, pointing towards an increased use of hold-separate provisions (whereby the relevant assets would be managed by an independent person from merger to divestment) and the need for shorter implementation periods in order to reduce the potential for crippling (ibid., pp.145 to 146).
} 
The EC Commission's Guidelines, clearly influenced by the FTC study, express a preference for the divestment of a stand-alone business. ${ }^{51}$ Nevertheless, the DG Comp study found surprisingly that the ratio of carveout to stand-alone divestitures was three to two. ${ }^{52}$ The former approach "of divesting solely the overlapping business has at times resulted in insufficient consideration of... critical commercial issues pertaining to the key requirement of viability of the divested businesses". ${ }^{53}$ It further highlighted the issue of identifying a suitable purchaser which, according to the results of the study, was often crucial to viability. ${ }^{54}$

The DG Comp study also underlined the importance of scrutinising the motivations of purchasers to the extent that "the interests of the purchasers typically do not fully coincide with the intended goal of the remedy". ${ }^{55}$ Such a (mis)alignment of incentives might exist where, for example, "purchasers find it preferable to pay a substantially lower price in return for fewer assets, with the negative result that they will not be as well-equipped to effectively compete against the seller". ${ }^{56}$ The report pointed to three cases in particular where the divested assets were purchased for free or at a negative price. ${ }^{57}$ This highlighted the need, by the use of business plans, to assess "whether

\footnotetext{
${ }^{51}$ EC Guidelines, cited above fn.14, para. 17. On the influence of the FTC study on EC merger practice see Monti, cited above, fn.3, p.3.

${ }_{52}$ DG Comp study, cited above, fn.34, p.150. In this context, carve-out means the legal and physical separation of the divested assets from the merging parties' retained business in order to correct for the horizontal overlap.

${ }^{53}$ ibid., p.141. For example, the horizontal overlap between the parties may exist in a narrow geographical market, but the scope of a viable business may not correspond to such a narrowly defined market. Where the scope of a viable business is beyond that of the market where there is an overlap, a suitable purchaser would be one who already was present in an geographically adjacent market so that it could realise the economies of scale and scope necessary for commercial viability. In such an instance, it is necessary to consider the counterfactual, however. If such a divestment forecloses entry by a firm which would otherwise have entered the market, then the divestment may well have an anti-competitive dimension. This is especially so in a market prone to coordinated effects because the divestment increases cost and price transparency and this would not otherwise have occurred if the divestee had otherwise entered.

${ }_{55}^{54}$ ibid.

${ }^{5}$ ibid., p.149 (emphasis supplied). For example, in one case involving a pre-merger collusive duopoly, and the divestee was an incumbent operator on the market, it emerged from interviews that the purchaser "competed only half-heartedly" with the merged entity with the consequence that the former "simply replaced" one of the two players in the pre-merger duopoly (ibid., p.103, footnote 275). Arguably, this is simply an example of restoring the status quo ante (a collusive duopoly) and does not signify the failure of a remedy as such.

${ }_{56}$ ibid., p.149.

57 ibid, pp.103 to 104.
} 
there was sufficient evidence of the purchaser's capability and incentives to compete actively". ${ }^{58}$ This goes further, therefore, than the FTC study where the emphasis had been upon the asymmetries of information and bargaining power in favour of the seller as against the buyer. ${ }^{59}$

Apart from the empirical evidence, using an economic model based on cooperative bargaining theory, Farrell offers a possible explanation for why and how the incentives of the agency and the buyer may become misaligned: he posits that the purchaser has a strong incentive to maximise the anticompetitive effects of the merger provided that the price paid for the divested assets reflects the benefits of increased market power to the merging parties. ${ }^{60}$ In other words, provided that there exists the necessary conditions for market power - such as capacity constraints or other barriers to entry - the buyer and seller have a positive incentive to collude in crippling the divested assets:

"[The buyer] has no incentives to insist on, or help the agency insist on, a divestiture package that truly preserves competition. Nor has it an incentive to demand key complements that will make the transferred assets competitively potent. Doing such competition-friendly things would shrink the financial pie to be divided between the buyer and the merging parties... .,61

This observation and the model underpinning it goes some way to explain why and how the price attached to the divested assets in question may assist in revealing the real incentives of both buyer and seller. Taken together with the results gleaned from the FTC and DG Comp studies, it underlines the fact that the identification of an appropriate buyer will often be critical to the success or otherwise of a merger remedy.

\footnotetext{
${ }^{58}$ ibid., p.104.

${ }^{59}$ Although the FTC study did include a discussion of some cases where it appeared that there was a misalignment of incentives as between the FTC and the purchaser (FTC study, cited above, fn.31, pp.26 to 27).

${ }^{60}$ Farrell "Negotiation and Merger Remedies: Some Problems" in Shelanski and Lévêque (eds.), cited above fn.3, p.97.

61 ibid. (original emphasis).
} 


\section{Judicial review of merger remedies: principles and pragmatism}

Under the Enterprise Act 2002, the CAT has a limited jurisdiction to review the merger decisions of both the OFT and the Competition Commission. Section 120(4) provides that in reviewing a merger decision the CAT "shall apply the same principles as would be applied by a court on an application for judicial review". ${ }^{62}$ In Somerfield $v$ Competition Commission ${ }^{63}$ - the first case involving a review of a Commission merger decision under this provision - the CAT took the opportunity to make a number of observations about the nature and extent of its reviewing function and, a related point, the "margin of appreciation" which is afforded to the Commission in merger decisions.

The background to the case originated with the divestiture by Morrisons of some 115 stores it acquired as part of its takeover of Safeways. These stores were purchased by Somerfield and post-transaction ${ }^{64}$ this concentration was referred to the Commission by the OFT ${ }^{65}$ The Commission concluded that the transaction resulted in a "substantial lessening of competition" (SLC) in respect of twelve local grocery markets, and by way of remedy it required Somerfield to divest itself of the twelve corresponding stores. ${ }^{66}$ The dispute centred on four of these stores. ${ }^{67}$

\footnotetext{
${ }^{62}$ The principles underlying the CAT's supervisory jurisdiction, a detailed consideration of which is outwith the scope of this work, were considered by the Court of Appeal in IBA Health $\checkmark$ OFT [2004] EWCA Civ 142. For a detailed discussion see Andrew Scott "The cutting of teeth: IBA Health v OFT" [2004] JBL 672; Femi Alesi "UK merger review and section 33: was the CAT not right" (2004) 25(8) ECLR 470.

${ }^{63}$ CAT judgment, cited above fn. 1 .

${ }^{64}$ The majority, but not all, of the relevant sotres had been purchased by Somerfield at the time.

${ }^{65}$ Somerfield is the fifth largest supermarket group in the UK.

${ }^{66}$ Competition Commission, Somerfield plc and Wm Morrison Supermarkets plc, A report on the acquisition by Somerfield plc of 115 stores from Wm Morrison Supermarkets plc (London: Competition Commission, 2005) (hereafter 'the Somerfield Report').

${ }^{67}$ In two markets Somerfield had closed the existing stores in favour of the acquired stores, and an exception here was appropriate given that the sale of the exiting store would cause less disruption to the market (ibid., [11.10]). In three cases the Commission were satisfied that there was no material difference between exiting and acquired stores (ibid., [11.20]). In a further three cases, Somerfield accepted the divestment of acquired stores (ibid., [11.14]). While Somerfield sought to bring these stores within the challenge, the CAT held that it should not be able to do so as it did not contest the decision of the Commission when it had the opportunity to do so (the CAT judgment, [71]).
} 
The CAT was faced with two key issues. First, whether the Commission was entitled to require the divestment of acquired stores rather than existing stores. In this regard, Somerfield argued that the Commission's approach went beyond that which was necessary to restore the status quo ante competitive position and was therefore impermissible. Secondly, the extent to which the Commission was entitled to restrict the pool of potential divestees, an issue crucial to the question of whether a suitable purchaser would be found. In the course of the judgment, the CAT also made a number of observations about the standard of proof the Commission was required to satisfy before taking a restrictive approach to the foregoing questions. These issues are particularly important given the level of deference which the courts have shown to the relevant agencies in the US and EC when dealing with questions over the scoping of remedies. ${ }^{68}$

\section{(a) Requiring the divestment of acquired rather than existing stores}

The general approach of the Commission was to require the divestiture of acquired rather than existing stores, while Somerfield argued that it should have a free choice. ${ }^{69}$ The Commission rejected this assertion:

"We do not ....accept Somerfield's argument that, as a matter of principle, it should generally be free to choose whether to divest the acquired or an existing store and that there is necessarily symmetry between divestment of either the acquired or existing stores. We are required to remedy the SLC and the adverse effects that have resulted from the merger, and this requirement determines the choice of store to be divested." ${ }^{\prime 70}$

By definition, the SLC would be addressed if the acquired store was divested, whereas the same was not necessarily true of the existing store. ${ }^{71}$ For the Commission, it was crucial that the stores offered for sale were sufficiently

\footnotetext{
${ }^{68}$ For a discussion of the US case law, see Baer and Redcay, cited above fn.3, pp.923-24; for the approach of the CFI, see Case T-342/00 Petrolessence SA v Commission [2003] ECR II1161.

${ }^{69}$ Somerfield Report, cited above fn.66, [11.9].

70 ibid., [11.13].

${ }^{71}$ ibid., [11.12].
} 
attractive to suitable purchasers and the sales were concluded within an "appropriate timetable":

"Where an existing store is relatively unprofitable, or has a significantly smaller sales area than an acquired store or has a disadvantaged store location, then there may be a significantly greater risk of not attracting a suitable purchaser and addressing the SLC., ${ }^{, 2}$

A suitable purchaser was defined as one who was able to offer comparable price, quality, range and service (PQRS) to that which was offered in the relevant store prior to the acquisition. ${ }^{73}$ In accordance with the guidelines (discussed above), the Commission rejected as irrelevant factors concerning the relative costs of disposing of existing or acquired assets when divestment was imposed post-transaction. ${ }^{74}$

Somerfield, on the other hand, claimed that the Commission's starting point in preferring divestment of acquired assets "was fundamentally wrong". ${ }^{75}$ The SLC was caused solely by the common ownership of the existing and acquired stores: since divestment of either type would restore the status quo ante, the Commission did not have the jurisdiction to go further and stipulate the type of store to be divested. ${ }^{76}$ The conclusion the Commission reached that a weaker store was "unsaleable or difficult to sell" was reached "impermissibly and without evidence": weaker stores may have been less attractive to a potential purchaser, but this was a factor which went to the price of the assets, rather than their saleability. ${ }^{77}$ Somerfield also alleged that the Commission had not really been concerned with the relative saleability of existing and acquired stores, but rather their comparable competitive weight which, according to Somerfield, was an irrelevant factor. ${ }^{78}$

\footnotetext{
72 ibid., [11.12].

73 ibid., [11.22].

74 ibid., [11.17].

${ }^{75}$ CAT judgment, [80].

76 ibid., [73 and 77]. This was particularly so, according to Somerfield, because the Commission in finding SLC had assumed "symmetry" in terms of competitive constraints between the acquired and exiting stores, but this had not been carried forward at the divestiture stage (ibid., [74]).

77 ibid., [73] and [80].

78 ibid., [80].
} 
The CAT noted that the starting point of the Commission to prefer the divestment of acquired assets was "entirely consistent" with its guidelines, the validity of which were not challenged by Somerfield. ${ }^{79}$ Indeed, given that the divestment guidelines were published prior to Somerfield's acquisition of the stores, it should have been aware of the approach the Commission would take in the light of a reference to it. ${ }^{80}$ In following the guidelines, and while leaving open the possibility of alternatives put forward by Somerfield, the Commission had "acted entirely reasonably". 81 Conversely, had the Commission departed from its guidelines "without good reason" it "may have been in difficulty". ${ }^{82}$ Overall, the general presumption in favour of the divestment of acquired assets as a post-transaction corrective to an SLC was not unreasonable:

"After all, it is the acquisition that has given rise to the SLC, so to reverse the acquisition would seem to us to be a simple, direct and easily understandable approach to remedying the SLC in question. While we can see Somerfield's argument that divestment of the existing, rather than the acquired, business may also remedy the SLC, that may not always be the case... and may in any event be less certain and direct." ${ }^{\text {}} 3$

In other words, the Commission was entitled to take into account the relative efficacy (in terms of certainty, directness and timeliness) of the alternative divestment remedies.

Somerfield also argued that because there was no requirement upon it to notify the transaction, the fact that it did not should not be held against it. ${ }^{84}$ Indeed, Somerfield alleged that the Commission was really concerned with penalising it for not having notified the transaction or, as the CAT put it, the "suggestion is that the [Commission] did not want Somerfield to profit by the transaction by, in effect, acquiring the 'better' store in a particular location and

\footnotetext{
79 ibid., [94 to 97$]$.

80 ibid., [97 and 100].

81 ibid., [98]

82 ibid..

${ }_{83}^{83}$ ibid., [99].

84 ibid., [77].
} 
then taking the opportunity to dispose of some of its poorer stores". ${ }^{85}$ The CAT accepted that if the Commission had focussed on Somerfield's "gain", rather than on remedying the SLC, then this approach would have been "questionable". ${ }^{86}$ It was "plain", however, that the purpose of requiring the divestiture of the acquired stores was because the existing stores were less likely to attract a suitable purchaser "with the consequence that the SLC would be remedied less quickly or effectively". ${ }^{87}$ There was no basis in fact that the Commission had "an ulterior motive or a different agenda". 88

\section{(b) The limitation on potential purchasers of the divested assets}

During the first stage of its inquiry, the Commission identified a competitor set which comprised those firms (or fascias) that acted, or had the potential to act, as a significant competitive constraint on Somerfield stores. Carrying this analysis forward into the remedies stage, it excluded Limited Assortment Discounters (LADs) from the range of potential divestees because they were not able to offer comparable PQRS to that on offer in the stores to be divested. ${ }^{89}$ The Commission set an initial divestiture period after which time the pool of potential divestees could be extended to include LADs (and others), but only if Somerfield could demonstrate that there was no interest in the assets from those in the competitor set. ${ }^{90}$ However, as a back stop, the Commission also indicated that if Somerfield was unable to show good reason for why, within the initial period, it was unable to reach agreements to divest with those in the competitor set, it would appoint a divestiture trustee to manage the sale of the assets. ${ }^{91}$

\footnotetext{
${ }^{85}$ ibid.. In this regard, Somerfield sought to rely on evidence of "a certain hostility to [its] legitimate commercial position" (ibid.).

${ }^{86}$ ibid., [114].

87 ibid.

${ }^{88}$ ibid., [115].

${ }^{89}$ Somerfield Report, cited above fn.66, [6.43 to $6.45,11.26$ to 11.27$]$. The main reason appeared to be the limited range of products these stores offered as compared with the others in the competitor set. The range of divestees was extended to include those not present in the relevant local markets but were able to offer comparable PQRS (ibid., [11.26]). ${ }_{50}$ ibid., [11.28]. This divestment period was to remain confidential "to prevent acquirers taking advantage of restrictions in the field of purchasers" (ibid., [11.31]).

${ }^{91}$ ibid., [11.33].
} 
Somerfield claimed that it was "perverse" to exclude LADs from the pool of potential divestees when other fascias, whose competitive impact on the divested stores was comparable to the LADs, were included. ${ }^{92}$ While not challenging the scope of the competitor set as such, given that the Commission identified the set on "an avowedly conservative basis" it was not appropriate to exclude others from the divestee pool. ${ }^{93}$

The CAT rejected this ground of challenge. It noted that the LADs were not excluded entirely from the divestee pool, but only during the initial divestment period. ${ }^{94}$ As to the Commission carrying forward its substantive assessment (including the identification of the competitor sets), the CAT pointed out that Somerfield had not challenged the Commission's substantive assessment, and while it did "not necessarily follow" that the same reasoning should be carried forward into the remedies stage, "in our view in the absence of evidence to the contrary it is not unreasonable for the [Commission] to have adopted a consistent approach across both these stages". ${ }^{95}$ In other words, the Commission was not required to revisit its substantive assessment at the remedies stage absent strong reasons for so doing. This point was further underlined by the CAT when it considered the standard of proof under which the Commission was operating.

\section{(c) The onus and standard of proof}

In the course of its judgment, the CAT made a number of observations over the onus and standard of proof relating to merger remedies. For example, Somerfield had asserted that the Commission had reached conclusions on saleability without adequate foundation. Looking to the relevant statutory provisions under which the Commission was operating, the CAT concluded

\footnotetext{
${ }^{92}$ CAT judgment, [146].

93 ibid., [148].

${ }^{94}$ ibid., [168]. It was further noted that even during that period LADs may have been entitled to purchase the divested provided that Somerfield could persuade the Commission that equivalent PQRS would be offered (ibid.).

${ }_{95}$ ibid., [169].
} 
that it was entitled to a "clear margin of appreciation" in deciding what action was "reasonable and practicable" for remedying the SLC. ${ }^{96}$ The CAT stressed the "considerable experience" that Commission members had "particularly in business and commercial matters" and it was, therefore, "entitled to bring that experience to bear when reaching judgments on particular matters". 97 For example, the inferences on saleability it drew from the relative unprofitability of the existing stores was not "outwith the [Commission's] margin of appreciation". 98 Furthermore, the administrative timetable for considering remedies was "relatively short" with the consequence that "it will not be practicable - nor in our view reasonable - to place the onus on the [Commission] to do extra work" at the remedies stage. ${ }^{99}$ Indeed, the opposite was the case:

"In our view, for reasons of practicality, in addition to the reasons already discussed, the onus is rightly placed on the merging parties to provide evidence to the [Commission] to satisfy the latter that [its] starting point should be displaced in the particular circumstances. We emphasise 'evidence', if necessary supported by expert opinion. Assertion will not suffice."100

Indeed, in relation to saleability, the CAT made clear that the Commission may have done more than it was required to do in satisfying the relevant standard of proof:

"...[l]f... the [Commission] considered that the test [for requiring the divestiture of acquired rather than existing stores] was whether there was a risk that no sale at all would take place, that, if we may say so, may have been to go further than the [Commission] needed to go. In our view, it would suffice for the [Commission's] purposes that there was a real risk that the sale of the existing store would be more problematic, or would take longer, from the point of view of finding a purchaser able to offer PQRS comparable to that offered before acquisition, the onus being on Somerfield to establish that such was not the case."101

\footnotetext{
${ }_{96}^{96}$ ibid., [87 to 88].

97 ibid., [123].

98 ibid..

99 ibid., [101].

100 ibid.. See also [105].

101 ibid., [116].
} 
As to the standard of proof, Somerfield claimed that the Commission had acted on the basis of weak evidence, in particular a consumer survey commissioned by it which Somerfield claimed was "unrepresentative of LADs". ${ }^{102}$ Somerfield further argued that in interpreting the results of the competitor impact assessment (CIA) that the Commission had undertaken, it had demonstrated an inconsistency of approach as between LADs and other fascias (who were included in the competitor set). ${ }^{103}$ According to Somerfield, while the data was misinterpreted, the competitor impact assessment was the only "serious piece of quantitative evidence". ${ }^{104}$ The other evidence, including the consumer survey, ${ }^{105}$ was "weak, devoid of real content and inconclusive" and it was wrong, therefore, for the Commission to attach more weight collectively to the other evidence than it did to its own CIA. ${ }^{106}$ Among this other evidence were the views of LADs that they did not consider Somerfield to be a competitor. Somerfield argued that the views of other operators "are obviously to be treated with considerable caution as they have good reason to answer such a question strategically" and were "not a sound basis on which the [Commission] could proceed". ${ }^{107}$ The Commission, on the other hand, argued that its approach to the competitor set had been consistent throughout. $^{108}$

As to the evidence, the CAT agreed with the Commission that it was entitled to look at all available evidence 'in the round' and the weight given to evidence was a matter for the Commission and not one ordinarily for the CAT. ${ }^{109}$ For all of these reasons it was plain that the Commission was entitled to have regard to "the totality of evidence", and the weight attached to any piece(s) of evidence was neither "perverse" nor "a manifest error of

\footnotetext{
102 ibid., [147].

103 ibid., [150].

104 ibid., [149].

${ }^{105}$ Somerfield claimed that the survey design had a "fundamental flaw" insofar as the switching rates that the survey disclosed were not adjusted to take into account factors such as relative store sizes and distances (ibid., [153]).

${ }_{106}$ ibid., [149].

107 ibid., [152].

108 ibid., [157].

109 ibid., [177] citing Tesco Stores $v$ Secretary of State for the Environment [1995] 1 WLR 759, 764 (per Lord Keith).
} 
appreciation", the relevant test in a judicial review of this nature. ${ }^{110}$ Given the restrictive nature of this test, and the need under section 120 to determine matters "expeditiously", it held itself to be "extremely reluctant to entertain applications... based on lack of or misinterpretation of evidence, unless the groundwork has been properly laid out" by the applicant, not least because otherwise the Commission "does not have a full opportunity to deal with the matter in its defence". ${ }^{111}$ On the present facts, this was all the more important because the "onus is on Somerfield to show that the [Commission] could not reasonably have come to the conclusion that it did, and not on the [Commission] to show that it had grounds for depriving Somerfield of a choice of store" to divest. ${ }^{112}$

\section{Conclusions}

In a long and considered judgment, the CAT reached a decision which is in line with the case law in the US and EC, demonstrating a high degree of deference to competition agencies when scoping divestiture remedies. Arguably, this is the appropriate approach given the need for the court to be sensitive to both the realities of procedural expediency and the possible (mis)alignment of incentives as between the merging parties and the agency. Since the publication of the FTC divestiture study (the results of which have been further bolstered by the DG Comp study), it has been plain that the seller of divestment packages will often have strong incentives to undermine the efficacy of the remedial outcome. In this case, Somerfield was seeking to dispose of its least attractive assets to its least effective competitors. In the light of the need to correct the SLC with a degree of certainty and timeliness, the Commission was entitled (as the CAT held) to scope a remedy which was most likely to restore the status quo ante market position. Furthermore, if the court had permitted the parties to disturb the substantive assessment upon which the SLC finding was based, the Commission's bargaining power in

\footnotetext{
110 ibid., [183].

111 ibid., [131].

112 ibid., [132].
} 
scoping remedies would have been undermined seriously. The CAT rightly showed self-restraint in this case and it is likely, therefore, that UK merger remedies will be more effective as a result. 